\section{Authors' affiliations}

Scott T Weiss, Harvard Medical School,

Respiratory, Environmental and Genetic

Epidemiology, Channing Laboratory, Brigham \&

Women's Hospital, Boston, Massachusetts, USA

Augusto A Litonjua, Harvard Medical School,

Channing Laboratory, Brigham and Women's

Hospital, Boston, Massachusetts, USA

Correspondence to: Dr Scott Weiss, Harvard Medical School, Respiratory, Environmental and Genetic Epidemiology, Channing Laboratory, Brigham \& Women's Hospital, Boston, MA 02115, USA; scott.weiss@channing. harvard.edu

Competing interests: None declared.

\section{REFERENCES}

1 Yunginger JW, Reed CE, O'Connell EJ, et al. A community-based study of the epidemiology of asthma. Incidence rates, 1964-1983. Am Rev Respir Dis 1992;146:888-94.

2 King ME, Mannino DM, Holguin F. Risk factors for asthma incidence. A review of recent prospective evidence. Panminerva Med 2004;46:97-110.

3 Bach JF. The effect of infections on susceptibility to autoimmune and allergic diseases. N Engl J Med 2002;347:91 1-20.

4 Romagnani S. The increased prevalence of allergy and the hygiene hypothesis: missing immune deviation, reduced immune suppression, or both? Immunology 2004; 1 12:352-63.

5 Strachan DP. Hay fever, hygiene, and household size. BMJ 1989;299:1259-60.

6 Cohen S. Social status and susceptibility to respiratory infections. Ann NY Acad Sci 1999:896:246-53.

7 Schwartz J, Weiss ST. Dietary factors and their relation to respiratory symptoms. The Second National Health and Nutrition Examination Survey. Am J Epidemiol 1990;132:67-76.

8 Weiss ST. Diet as a risk factor for asthma. Ciba Found Symp 1997;206:244-57.

9 Devereux G, Turner SW, Craig LC, et al. Low maternal vitamin $E$ intake during pregnancy is associated with asthma in 5-year-old children. Am J Respir Crit Care Med 2006; 174:499-507.

10 Devereux G, Litonjua AA, Turner S, et al. Maternal vitamin $D$ intake during pregnancy and early childhood wheezing. Am J Clin Nutr 2007;85:853-9.

11 Litonjua AA, Rifas-Shiman SL, Ly NP, et al. Maternal antioxidant intake in pregnancy and wheezing illnesses at 2 years of age. Am J Clin Nutr 2006:84:903-11

12 Camargo JCA, Rifas-Shiman SL, Litonjua AA, et al. Maternal intake of vitamin $D$ during pregnancy and risk of recurrent wheeze in children at age 3 years. Am J Clin Nutr 2007;85:788-95.

13 Hollis BW, Wagner CL. Assessment of dietary vitamin $D$ requirements during pregnancy and lactation. Am J Clin Nutr 2004;79:717-26.

14 Hollis BW, Wagner CL. Nutritional vitamin D status during pregnancy: reasons for concern. CMAJ 2006;174:1287-90.
15 Hollis BW, Wagner CL, Drezner MK, et al. Circulating vitamin $D(3)$ and 25 -hydroxyvitamin $D$ in humans: an important tool to define adequate nutritional vitamin D status. J Steroid Biochem Mol Biol 2007; 103:631-4

16 Raby BA, Lazarus R, Silverman EK, et al. Association of vitamin $D$ receptor gene polymorphisms with childhood and adult asthma. Am J Respir Crit Care Med 2004; 170:1057-65.

17 Gregori S, Casorati M, Amuchastegui S, et al. Regulatory T cells induced by $1 \alpha, 25$ dihydroxyvitamin D3 and mycophenolate mofeti treatment mediate transplantation tolerance. J Immunol 2001;167:1945-53.

18 Gregori S, Giarratana N, Smiroldo S, et al. A $1 \alpha, 25$-dihydroxyvitamin $D(3)$ analog enhances regulatory T-cells and arrests autoimmune diabetes in NOD mice. Diabetes 2002:51:1367-74.

19 Meehan MA, Kerman RH, Lemire JM. 1,25Dihydroxyvitamin D3 enhances the generation of nonspecific suppressor cells while inhibiting the induction of cytotoxic cells in a human MLR. Cell Immunol 1992;140:400-9.

20 Hypponen $E$, Sovio $U$, Wist $M$, et al. Infant vitamin $D$ supplementation and allergic conditions in adulthood: northern Finland birth cohort 1966. Ann NY Acad Sci 2004; 1037:84-95.

21 Gale C, Robinson S, Harvey N, et al. Maternal vitamin D status during pregnancy and child outcomes. Eur J Clin Nutr, 2007 (Epub ahead of print).

22 Willers SM, Devereux G, Craig LCA, et al. Materna food consumption during pregnancy and asthma, respiratory and atopic symptoms in 5-year-old children. Thorax 2007:62:773-9.

\title{
Air pollution, human health, climate change and you
}

\section{George Thurston}

\section{The "co-benefits" of reducing air pollution on climate change and human health}

$\mathrm{T}$ he study by Ko $e t \mathrm{al}^{1}$ in this issue of Thorax (see page 780) provides an important new contribution to the growing body of evidence that the severe adverse health effects of air pollution, so well documented in Europe and North America, are also occurring in Asia. Indeed, a recent report by the Health Effects Institute (HEI) surveyed the available published literature on this topic as part of its Public Health and Air Pollution in Asia-Science Access on the Net (PAPASAN) study. They found hundreds of published studies showing adverse health effects of air pollution in Asia and summarised the results on the web (http://www.healtheffects.org/Asia/papasan-home.htm). These results show that a wide range of health effects are significantly associated with air pollution exposures in Asia, including studies of respiratory and cardiovascular morbidity and mortality in a number of cities across Asia. In fact, the HEI report identified 69 published studies of the effects of air pollution on the health of populations in Mainland China, 16 in Hong Kong, 56 in Taipei, China, 8 in Indonesia, 2 in Malaysia, 6 in Singapore, 13 in Thailand, 30 in India, 46 in Japan and 33 in South Korea. The study by Ko et al now adds to this knowledge by identifying a susceptible population not studied extensively before in Asia-people suffering from chronic obstructive pulmonary disease, the fifth largest cause of death in Hong Kong.

Clearly, there is a large body of studies documenting an ever widening range of adverse health effects of air pollution in
Asia. As summarised in the HEI report, the increased cardiopulmonary risks found in Asia are similar in magnitude, per amount of pollution, to the relative risks found in other parts of the world. ${ }^{2}$ But the importance of these increased risks for illness, hospital admissions and mortality are much greater than in Europe or North America because the levels of air pollution in Asia are usually so much higher. For example, the populations of Hong Kong and New York City are both about 8 million, but the annual average concentration of particulates with an aerodynamic diameter $<2.5 \mu \mathrm{m}\left(\mathrm{PM}_{2.5}\right)$ in Hong Kong, as reported by Ko et al, ${ }^{1}$ is nearly triple that found in New York $\left(36 \mu \mathrm{g} / \mathrm{m}^{3}\right.$ vs approximately $\left.14 \mu \mathrm{g} / \mathrm{m}^{3}\right)$. And, as shown in fig 1, Hong Kong has among the cleanest air of Asian cities. Air pollution represents a major, and growing, public health problem in Asia. Indeed, the World Health Organisation (WHO) has estimated that urban air pollution contributes each year to approximately 800000 deaths and 4.6 million lost life-years worldwide. ${ }^{4}$ As the population and economic activity of Asia grows, and as the migration of residents from the rural countryside to the cities accelerates, the outdoor air pollution health problems will continue to worsen unless measures are taken to reduce emissions of air pollutants by industrial, motor vehicle and fossil fuel combustion sources. 

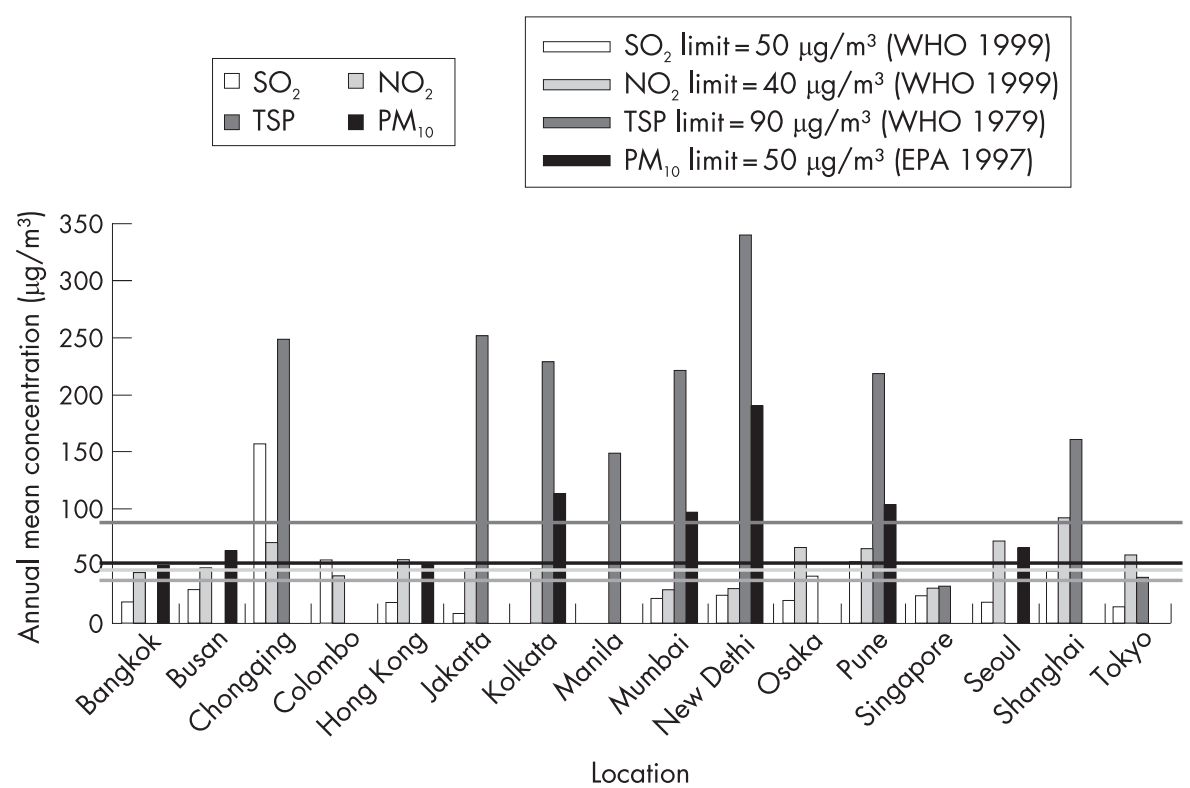

Figure 1 Comparative air pollution levels across $A$ sia. ${ }^{2} \mathrm{SO}_{2}$, sulphur dioxide; $\mathrm{NO}_{2}$, nitrogen dioxide; $\mathrm{TSP}$, total suspended particulate matter; $\mathrm{PM}_{10}$, particulates with an aerodynamic diameter $<10 \mu \mathrm{m}$. Reprinted with permission from the Health Effects Institute, Boston, USA.

The results of the work by Ko et al, ${ }^{1}$ combined with past such studies, also have potentially critical relevance to the challenge of climate change that faces all nations of the world. The most recent Intergovernmental Panel on Climate Change (IPCC) report ${ }^{5}$ has concluded, in the most definitive terms yet, that global climate change is occurring, stating that: "Warming of the climate system is unequivocal, as is now evident from observations of increases in global average air and ocean temperatures, widespread melting of snow and ice, and rising global average sea level". The fact that the "man-made" contribution to the climate change pollutants is largely caused by the same activity that causes the air pollution discussed by Ko et al indicates that, if a city, state, or nation acts to reduce the combustion of fossil fuels and the air pollution caused by them, it will reap not only the climate change benefits but also the localised health benefits associated with that reduction in air pollution. This point was brought home by a recent Policy Forum entitled Hidden Health Benefits of Greenhouse Gas Mitigation that appeared in the journal Science. ${ }^{6}$ The article concludes: "Policies to mitigate GHG can yield substantive and immediate benefits to the 3 billion people currently residing in urban areas throughout the world. Moreover, these largely unappreciated air pollution reduction-related health benefits could be a strong motivator for GHG mitigation action." Thus, the greatest air pollution health benefits of climate control measures will go to the cities and countries that act most vigorously to control their combustion emissions of greenhouse gases. These locally enjoyed health "co-benefits" of reductions in air pollution should be a major inducement for individual governments to "sign on" to act to reduce climate change pollution.

Public survey polls have shown that scientists and physicians, such as you who read this journal, are among the people most respected by the general public. Not politicians, not lawyersyou. In addition to this credibility and stature, you now also have the information necessary to induce your own city, state and nation to go forward with reducing pollution from the combustion of fossil fuels; if they act to reduce this fossil fuel burning pollution, there will not only be long-term global climate change benefits but also immediate local health benefits that will be reaped from controlling this air pollution. You now have the facts: it is up to you to carry this simple message to your respective governments about air pollution, climate change and health effects: "Think globally, benefit locally".

Thorax 2007;62:748-749.

doi: 10.1136/thx.2007.079228

Correspondence to: Dr George Thurston, New York University School of Medicine, Nelson Institute of Environmented Medicine, 57 Old Forge Road, Tuxedo, NY 10987, USA;

Thurston@env.med.nyu.edu

Competing interests: None.

\section{REFERENCES}

1 Ko FWS, Tam W, Wong TW, et al. Temporal relationship between air pollutants and hospital admissions for chronic obstructive pulmonary disease in Hong Kong. Thorax 2007;62:780-85.

2 HEI International Scientific Oversight Committee. Health effects of outdoor air pollution in developing countries of Asia: a literature review. Special Report 15. Boston, Massachusetts: Health Effects Institute, 2004.

3 Cifuentes L, Borja-Aburto V, Gouveia N, et al. Assessment of the urban air pollution benefits of global warming mitigation: Santiago, São Paulo Mexico City, and New York City. Environ. Health Perspect 2001;109(Suppl 3):419-25.

4 World Health Organisation. The World Health Report 2002: reducing risks, promoting healthy life. Geneva: World Health Organisation, 2002.

5 Intergovernmental Panel on Climate Change (IPCC). Climate change 2007: the physical science basis. Summary for policymakers. Contribution of Working Group I to the Fourth Assessment Report of the Intergovernmental Panel on Climate Change. Geneva: IPCC Secretariat, 2007.

6 Cifuentes L, Borja-Aburto VH, Gouveia N, et al. Climate change. Hidden health benefits of greenhouse gas mitigation. Science 2001;293:1257-9.

Access the latest content chosen by our Editors

BMJ Journals editors select an article from each issue to be made free online immediately on publication. Other material is free after 12 months to non-subscribers. Access the Editor's Choice from the home page - or expand your horizons and see what the other BMJ Journals editors have chosen by following the links on any BMJ Journal home page. 